\title{
Role of Innovation and Business Model Application in Rattan Craft Industry of Micro, Small and Medium-Sized Enterprises (SMEs) in Cirebon Regency
}

\author{
Ida Hindarsah \\ Business Administration Department, Faculty of Social Sciences and Politics, \\ Pasundan University, Bandung, Indonesia
}

\begin{abstract}
The rattan craft centers in West Java, Cirebon regency, located in three districts, namely: Tegal Wangi, Plumbon and Weru. Type of business is Micro, Small and Medium-sized Enterprises (SMEs) and large enterprises. Several rattan companies owned by foreign entrepreneurs who manufacture furniture and have a special market in abroad. In recent years, the productivity of the rattan craft centers decreased. The decline is mainly occurred in the company of Micro and SMEs which have limited capital, conventional management, not having a business strategy, lack of technology and simple equipment, unskilled craftsmen and so on. Most of Micro and SMEs entrepreneurs produce products for the local and domestic market. Its products include furniture, interior products, baskets and others. Their customers are hotel, restaurant, residential, office and furniture retailer. The production process is done by the sub contract to groups of craftsmen. The jobs are distributed to several groups of craftsmen who adapted to his specialty such as processing raw materials worker, frame maker, basket wicker, painting or coating worker. While wages system based on the work or the entire stock of work. In general, most of the work finishing or coating undertaken by the SMEs themselves so that the result is the same and the quality is guaranteed. Moreover, the process requires special equipment that is not shared by all craftsmen. While large manufacturer rarely do the sub contract system but produce it in their factory. Thus, the product quality is guaranteed and high. In order to face the global market needed an innovation that rattan craft businesses can survive and be able to compete with other competitors. Ironically, the understanding of innovation among Micro and SMEs entrepreneurs of rattan craft centers in Cirebon regency is still low. There are various factors that caused the lack of innovation, for instance, most rattan entrepreneurs have mainly manufactures products on orders from buyers or agent. So that their innovation potential does not arise because there is no challenge. Only a few local rattan entrepreneurs who innovate, for instance, Indah Rattan Furniture and Handicraft workshop owned by Nemo. He is a pioneer of rattan industry in Cirebon regency. In addition, Micro and SMEs entrepreneurs doing the business in conventional ways without a specific strategy in the face of market competition. While the dynamic nature of the global market that requires innovative products and innovative business strategies. In an effort to deal with the dynamics and the market increasingly competitive market conditions, it is necessary to make some special efforts so that rattan entrepreneurs can endure. On the effort in developing rattan craft industry the innovative design is really required. In addition, the development, in this case, can be done through several ways, such as: implement business models. In short, both aspects is effective in efforts to develop the industry of rattan-based Micro and SMEs in Cirebon regency.
\end{abstract}

Keywords: Innovation; Micro entrepreneur; SMEs; Business model.

\section{Introduction}

The rattan craft centers in West Java, Cirebon regency, located in three districts, namely: Tegal Wangi, Plumbon and Weru. These districts has the largest rattan industry not only in West Java provinve but also in the country. These craft rattan industries established since 1960s and they have much experiences on craft rattan. Type of business is Micro Enterprises (MIEs), Small and Medium-sized Enterprises (SMEs) and large enterprises.n Definition of Micro business:"... is the economic activity that carried out either by individuals or households and a body, a number of the employee are 1-4. Small businesses are the economic activity that is carried out either by individuals or households and a body, the number of the employee are 5-19" [1]. West Java province have approximately 9.042.519 MIEs of variety industries and absorbed 13.861.814 informal labor in 2012. This shows that the MIEs have strategic role in the regional and national economy in Indonesia. Rahmaniar stated: "According to Ministry of Cooperatives and Small and Medium Enterprises of Indonesia in the First National Work Meeting in 2005, Micro, Small, and Medium-sized Enterprises in Indonesia are major players in economic 
activity in various sectors, the largest provider of employment, significant players in development of social economic activities and empowerment, and also the creator of new markets and source of innovation"[2]. Besides, that the majority of SMEs are MIEs: " The majority of SMEs are MIEs, which are dominated by selfemployed individuals without wage-paid workers. However, many MIEs are established by poor households or individuals who cannot find better job opportunities elsewhere, either as their primary or secondary (supplementary) source of income. Therefore, the presence of many MIEs in both rural and urban areas in Indonesia is considered to be the result of the country's current unemployment or poverty problem and is not seen as the reflection of an entrepreneurial spirit SMEs in developing countries such as Indonesia are often characterized by low productivity, which mainly caused by their lack of capital, access to technology, and human capital. As in other developing countries, Indonesian SMEs, particularly MIEs and small enterprises, are often hampered by institutional constraint. Although these constraints my differ across sectors and regions, there are number of common problems, including the lack of capital, human resources, technology and information; difficulties in procuring raw materials; weak marketing and distribution capacity; high transportation costs; cumbersome and costly bureaucratic procedures (particularly in obtaining licenses to operate); and policies and regulations that generate market distortions. All theseare often referred to as external contraints to the growth of SMEs"[3]. According to Tulus that micro business conditions in Indonesia are as follows:"In fact, SMEs developing countries such as Indonesia are often characterized by low productivity, which is mainly caused by their lack of capital, access to technology, and human capital[3].Several rattan companies owned by foreign entrepreneurs who manufacture furniture and have a special market in abroad. These companies are managed by professional management, high technology and the manufacture of export products

In recent years, the productivity of the rattan craft centers decreased. The problem is mainly occurred in the company of Micro and SMEs who have limited capital, conventional management, not having a business strategy, lack of technology and simple equipment, unskilled human resources craftsmen and so on. The problem of rattan industry was also caused by the previous government policy which allow export of raw rattan. It caused rattan industries in Cirebon regency decreased because the biggest market of rattan product in abroad. Other problem is many rattan craftsmen change their profession because the wage is greater than a rattan craftsmen's wage. In 2013 the export of rattan products in Cirebon regency reached an average of 1,200 containers/month. Industries need \pm 6000-7200 tons per month of raw rattan. Most rattan products export to USA, Europe, and several Asian countries but rattan products sold in the country are few in number. Rattan industry in Cirebon regency increase after the government through the Ministry of Commerce to stopped export of raw rattan end of 2011. In 2005 to 2011 rattan production decreased due to the previous policy of Trade Minister to permit export of raw rattan to abroad.

According Furkan:"Most of the Indonesian craft industry is home-based industries where hand-made products are the main product. They have good skills combined with local values and wisdom in producing the craft products. Most of the craftsmen produce craft products by hand with feeling and artistic merit" [4]. The jobs are distributed to several groups of craftsmen who adapted to his specialty such as processing raw materials worker, frame maker, basket wicker, painting or coating worker. While wages system based on the work or the entire stock of work. In general, most of the work finishing or coating undertaken by the SMEs themselves so that the result is the same and the quality is guaranteed. Moreover, the process requires special equipment that is not shared by all craftsmen. While large manufacturer rarely do the sub contract system but produce it in their factory. Thus, the product quality is guaranteed and high.

In order to face the global market needed an innovation that rattan craft businesses can survive and be able to compete with other competitors. Ironically, the understanding of innovation among Micro and SMEs entrepreneurs of rattan craft centers in Cirebon regency is still low. There are various factors that caused the lack of innovation, for instance, most rattan entrepreneurs have mainly manufactures products on orders from buyers or agent so they have no innovative experiences. Understanding on innovation among MIEs or SMEs entrepreneurs and government is still low. The reason is that the company can run even without innovation. Whereas in the context of the global economy, including its impacts, prompting the need for innovation in MIEs businesses is needed which impact of globalization has driven innovative products:" Globalization has led to new markets for innovative products as well as new production locations for them - Asia being the prime 
example of both [5]. These impacts also affect the national economy of Indonesia, including MIEs effort:"Innovation is a central driver of economic growth and development. Firms rely on innovation and related investment to improve their competitive edge in a globalizing world with shorter product life cycles. In recent decades, economist and policymakers have increasingly focused on innovation and its diffusion as critical contributors to economic growth and development [5]. There are strong impact globalization on MIEs and SMEs businesses: "Globalization has led to new markets for innovative products as well as new production locations for them- Asia being the prime example of both [5].

In general their innovation potential does not arise because there is no challenge. Only a few local rattan entrepreneurs who innovate, for instance, Indah Rattan Furniture and Handicraft workshop owned by Nemo who is one of pioneers of rattan industry in Cirebon regency. He did a lot of innovation in order to solve the problem of limited tool, lack of technology, bad raw materials, limited techniques and so on. In addition, most of MIEs is lack of capital and technology and unskilled workers. In general, small rattan craft industry in Cirebon regency still uses handmade techniques with simple tools.
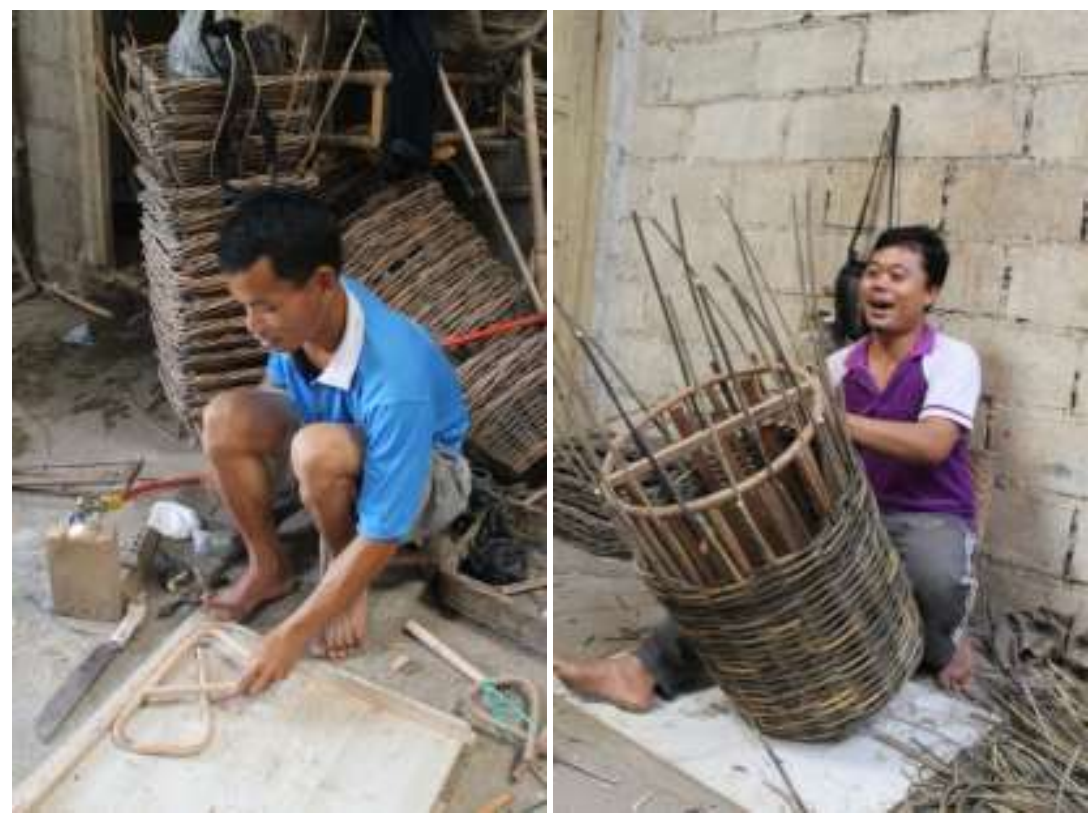

Fig. 1 Rattan craft workers in Cirebon regency produce products by simple tools. Most of them are uneducated workers who have self-taught skills.

In addition, Micro and SMEs entrepreneurs doing the business in conventional ways without a specific strategy in the face of market competition. Sandu affirms in Lobontiu that the most important characteristics of the SME strategies are the folowings: 1) Most of SMEs are applying intuitive or a kind of empirical strategies, which are not formalized and they can be deduced from the entrepreneur behavior. Often, those 'strategies'are shaped into an 'idea' of the entrepreneur regarding the future evolution of the company and the most important steps that have to be done; 2) The strategy application process has limited impact on the SME structure. The small size of the entreprise is not allowing the use of the most common structure applied in the big companies; the firm stays compact and it accepts only fundamental and essential structures;3)The strategic horizon of the small and medium sized business is also limited because of the bigger uncertainties of their enviromment; 4)For a SME. The strategic concept has to be more flexible, in order to be able to take advantage of the forthcoming opportunities or to avoid external threats. Competitive strategies can be regarded as specific business strategies. They are aimed at the development of competitive advantages for particular product/market combinations (business) [5]. While the dynamic nature of the global market that requires innovative products and innovative business strategies. 


\section{Literature Review}

\subsection{Innovation}

The Oslo Manual defines four types of innovation: product innovation (new goods or services or significant improvements to existing ones), process innovation (changes in production or deliverymethods), organizational innovation (changes in business practices, workplace organization or in a firm's external relations) and marketing innovation (changes in product design, packaging, placement, promotion or pricing) [6]; According to Drucker in Furkan:" Innovation in the firm is a multidimensional concept. An innovation can be defined as "an idea, practice, or object that is perceived as novel by an individual or other unit of adoption."Drucker describes innovation as the effort to create purposeful, focused change in an enterprise's economic or social potential" [4]; According to Thomas: "The inter-relationship between invention, innovation and entrepreneurship is both of theoretical and practical significance. It may involve inventors and entrepreneur in all aspects of the process of product, process or service development but also it can involve them separately." [7]; Lundstörm stated that globlal world is the world of entrepreneur and innovations: "One main conclusion is that changes by globalization will affect the SMEs and entrepreneurs in different type of economies both on a national and regional perspective. The world is globalized so is the world for entrepreneurs and innovations. All type companies will be affected by the changes that one nowadays could observe, not only SMEs or the behaviour of multinationals and large firms, and the relations between large and small firms"[8]. Drucker stated there is relationship between innovation and entrepreneneurship: "Today, much confusion exist about the proper definition of entrepreneurship, some observers use the term to refer to all small businesses; others, to all new businesses. In practice, however, a great many well - established businesses engage in highly successful entrepreneurship. The term then refers not to an enterprises size or age but a certain kind of activity. At the heart of that activity an innovation " [9]. Innovation is vital aspect on economic development: "Indeed, the experience of several East Asia economies has demonstrated how innovation can spur economic catch - up - even if innovation may be only part of the success story of those economies [6] ; The role of innovation in the context of modern market economies is vital, as stated below: In modern market economis, innovation is a key ingredient of sustained economic growth. In high-income countries, studies have estimated that innovation accounts for as much as 80 percent of economy-wide growth in productivity [6]; Application of innovation is not only on technology but also non technological aspect:" Studies also pointed to the importance of non-technological innovation-including organizational, marketing, design and logistical innovation-as an important driver of firm and economy-wide productivity enhancements. [6].

There are two types of development for MIEs or SMEs with institution namely: "Horizontal" collaboration with similar firms is one important element of open innovation, but it also includes "vertical" cooperation with customers, suppliers, universities, research institutes and others [6]; The role of government and universities in the development of rattan in Cirebon regency still minimal. Though their role is very important:" Universities and PROs play a key role in national innovation systems. They also perform most of the basic research carried out in their countries. This is especially so in middle-income countries; for example, the share of universities and PROs in total basic research is close to 100 percent for China, 90 percent for Mexico and 80 percent for the Russian Federation [6]. The goal is that between policy and implementation can run well. Often there is overlap between the programs of each other; program does not match with market needs and conditions of the company. Ideally, the government should adopt the innovation programs of these countries. In fact, subsidized credit, various training programs and subcontracting schemes which provided by government were not successful in their implementation.

\subsection{Business Model Application}

Most MIEs and SMEs rattan craft entrepreneurs use traditional business. They should have any business model for their development. Definition of business model: "An architecture for product, service and information flows, including a description of various business actors and their roles; and description of the potential benefit for the various business actor; and a description of the source revenues [10]; Rappa in Osterwalder stated that: "In the most basic sense, a business model is the method of doing business by which a company can sustain itself -- that is, generate revenue. The business model spells-out how a company makes money by specifying where it is 
positioned in the value chain [10]; Afuah and Tucci stated that:"This [the Internet business model] is a set of Internet-related activities - planned or evolving - that allows a firm to make money using the Internet and to keep the money coming [10] ; According to Margaretta:"A good business model begins with an insight into human motivations and ends in a rich stream of profits. They are ... stories - stories that explain how enterprises work. A business model describes, as a system, how the pieces of a business fit together [10].

Business models specify the relationships between different participants in a commercial venture, the benefits and costs to each and the flows of revenue. Business strategies specify how a business model can be applied to the market to differentiate the firm from its competitors. Osterwalder and Pigneur define :"Business models can be seen as the missing link between strategy and business processes or in other words the linkage between the planning and the implementation level of a business environment "; According to Bouwman: A business model is a blueprint that describes how a network of cooperating organizations intends to create and capture value" business models for the networked enterprise." He states there four main domains in business models:1) Service domain: a description of the service offering, its added value, and the market segment at which the offering is targeted;2) Technology domain: a description of the technical functionality required to realize the service offering' 3) Organization domain: a description of the structure of the multi-actor value network required to create and distribute the service offering (organizational arrangements);4) Finance domain: a description of how risks, investments and revenues are divided over the different actors of a value network (financial arrangements) [10].

\section{Conclusion}

In an effort to deal with the dynamics and the market increasingly competitive market conditions, it is necessary to make some special efforts so that rattan entrepreneurs can endure. On the effort in developing rattan craft industry the innovative design is really required. In addition, the development, in this case, can be done through several ways, such as: implement business models. The implementation is a necessity in Mies effort in order to survive in the global competition. In general, SMEs entrepreneurs do not recognize and use a business model, but doing business with simple management.

In short, both aspects is effective in efforts to develop the industry of rattan-based Micro and SMEs in Cirebon regency.The goal is that the rattan industry to compete in global and domestic markets. The role of the government as one of the elements Intellectual, Business and Government (IBG) very important in realizing the above aspects. Including implementing policies that support both the above aspects.

\section{References}

[1] Hadiyati. Ernani, "Marketing and government policy on MSMEs in Indonesian: A theoritical framework and empirical study," International Journal of Business and Management, vol. 10, pp. 128-141, 2015.

[2] Merlyn. Rakhmaniar and Gatot. Yudoko, "Low Cost Product Development Framework for Micro Sized Enterprises: Some Indonesian Evidence, International Journal of Economics and Management, vol. 8 (1), pp. 125-138, 2014.

[3] Tulus, Tambunan, The Impacts of Trade Liberalization on Indonesian Small and Medium-sized Enterprises, Winnipeg, Manitoba, Canada.: International Institute for Sustainable Development, 2011, pp. 6-7.

[4] Lalu. M. Furkan and Nubotaka. Odake, Best Practice of Innovation Among the Indonesian Craft Industry Cluster: Lesson Learnt from Indonesia. Nagoya, Japan.: Nagoya Institute of Technology, 2014, pp.1254- 1256.

[5] Gabriela.Lobontiu, Strategies and Strategic Management in Small Business, Copenhagen.: Copenhagen Business School, 2002, pp.7-8.

[6] World Intellectual Property Right. The changing Face of Innovation, Geneva.: World Intellectual Property Right, 2011, pp. 4-28.

[7] Brychan. Thomas, Christoper. Miller, Lyndon. Murphy, Innovation and Small Business-Volume $1.1^{\text {st }}$ ed. Bookboon.com, 2011, pp. 8.

[8] Anders. Lundstörm, The Role of SMEs and Entrepreneurship in A Globalized Economy, Stockholm.: The Globalization Council, 2009, pp. 8.

[9] Peter. F. Drucker,The Dicipline of Innovation. Harvard: Harvard Business School Publishing Corporation, 2002, pp. 6.

[10] Alexander. Osterwalder and Yves. Pigneur, BusinessModel Generation, Amsterdam: Self Published, 2009, pp. 14-39. 